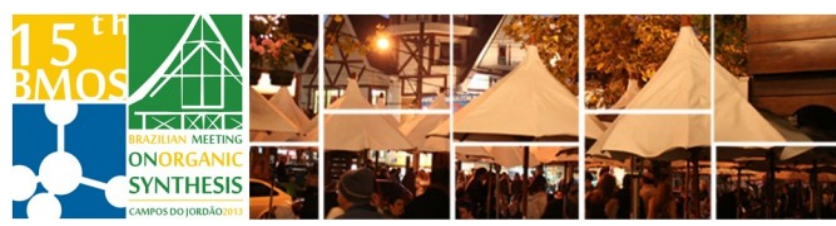

\title{
New strategy for the synthesis of Bromacil and their analogous
}

\author{
Nilo Zanatta, Josiane M. dos Santos*, Alessandra da Silveira, Hélio G. Bonacorso e \\ Marcos A. P. Martins.
}

\author{
Núcleo de Química de Heterociclos (NUQUIMHE)- Departamento de Química, Universidade Federal de \\ Santa Maria, Av. Roraima, 1000, Bairro Camobi, 97.105-900, Santa Maria, RS, Brasil. \\ *Autor, e-mail: jom.dossantos@yahoo.com.br \\ Keywords: bromination, 5-bromo uracil, analogous Bromacil
}

\section{INTRODUCTION}

The introduction of halogenes and halogenated groups in organic molecules promotes significant changes in their chemical, physical and biological properties ${ }^{1}$. Halogenation reactions at position 5 of uracils and pyrimidinones has been applied to obtain new substances with biological, industrial and commercial concern. ${ }^{2,3}$ As the examples we cited Bromacil (I)(Herbicide) and 5-Fluorouracil (II)(Antitumor) ${ }^{4}$ (Figure 1). Furthermore, 5halouracilas can be used as synthetic intermediates in coupling reactions. ${ }^{5}$

In this work we present the synthesis of 5-bromo uracils (14-17), the Bromacil analogous, through a methodology quickly and efficiently.

\section{RESULTS AND DISCUSSION}

The 5-bromo uracil synthesized in this work, were obtaneid according to Scheme 1. Firstly, the 2methylthiopyrimidin-4(3H)-ones (6-9) were obtaneid from the cyclocondensation reaction of $\beta$-alkoxyvinyl trihalomethyl ketones (1) with asymmetric 1methylisothiourea sulfates (2-5) in solution of $\mathrm{Na}_{2} \mathrm{CO}_{3} 1 \mathrm{M}$. The 2-methylthiopyrimidin-4(3H)-ones (6-9) were oxidized with OXONE in a mixture of $\mathrm{MeOH}-\mathrm{H}_{2} \mathrm{O}$ as solvent and refluxing to form uracil of interest (10-13). From the bromination reaction between $1.0 \mathrm{mmol}$ of uracil (10-13) with $1.5 \mathrm{mmol}$ of $\mathrm{Br}_{2}$ dissolved in $10 \mathrm{~mL}$ of $\mathrm{MeOH}$, the 5-bromo uracils (14-17) were synthesized. The reaction is carried at room temperature for $10 \mathrm{mim}$. After completion of the reaction time, the precipitate is filtered and dried under vacuum. All products were obtained off as solids. Purification of the compounds was carried out by recrystallization using $\mathrm{CHCl}_{3}$ and $\mathrm{MeOH}$. The identification of 5-bromo uracils was performed by ${ }^{1} \mathrm{H}$ and ${ }^{13} \mathrm{C}$ NMR and Mass Spectrometry.<smiles>CCC(C)n1c(=O)[nH]c(C)c(Br)c1=O</smiles><smiles>O=c1[nH]cc(F)c(=O)[nH]1</smiles>

Figure 1. Chemistry structure of Bromacil and 5Fluorouracil
Scheme 1:

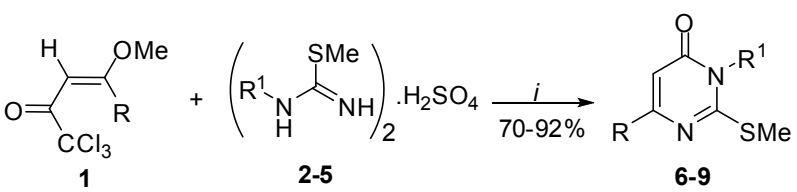

$$
\begin{aligned}
& \underset{64-90 \%}{i i}
\end{aligned}
$$

$i=\mathrm{Na}_{2} \mathrm{CO}_{3}(1 \mathrm{~N})$, t.a, 1-4h; $i i=\mathrm{OXONE}, \mathrm{MeOH} / \mathrm{H}_{2} \mathrm{O}, \Delta, 15 \mathrm{~h}$; $\mathrm{iii}=\mathrm{Br}_{2}$, MeOH, t.a, $10 \mathrm{~min}$

\begin{tabular}{|c|c|c|c|c|c|c|c|}
\hline $1,14-17$ & a & & b & c & d & e & f \\
\hline $\mathbf{R}$ & $\mathrm{Me}$ & & Dh & 4-Me- $\mathrm{C}_{6} \mathrm{H}_{4}$ & 4-OMe- $\mathrm{C}_{6} \mathrm{H}_{4}$ & $4-\mathrm{F}-\mathrm{C}_{6} \mathrm{H}_{4}$ & 4-Br- $\mathrm{C}_{6} \mathrm{H}_{4}$ \\
\hline 2,14 & 3,15 & 4,16 & & & & & \\
\hline $\mathrm{R}^{1} \mathrm{Me}$ & $\mathrm{Ph}$ & $\mathrm{Bn}$ & & & & & \\
\hline
\end{tabular}

\section{CONCLUSION}

In summary, we presents the synthesis of a new series of 5-bromo uracil (14-17), analogous of the Bromacil, through of a methodology quickly, efficiently and high yields.

\section{ACKNOWLEDGEMENTS}

The authors acknowledge the financial support of the National Council Scientific and Technological Research (CNPq), CAPES and FAPERGS

\section{REFERENCES}

${ }^{1}$ Ondi, L.; Lefebvre, O.; Schlosser, M. Eur. J. Org. Chem. 2004, 17, 3714. ${ }^{2}$ Barret, H. B.; Goodman, I.; Dittmer, K. J. Am. Chem. Soc. 1948, 70, 1753.

${ }^{3}$ Skulnick, H. I.; Ldens, J. H.; Wendling, M. G.; Glenn, E. M.; Rohloff, N. A.; Smith, R. J.; Wierenga, W. J. Med. Chem. 1986, 29, 1499.

${ }^{4}$ Miyaschita, O.; Matsumura, K.; Shimadzu, H.; Hashimoto, N. Chem. Pharm. Bull. 1981, 29, 3181.

${ }^{5}$ Kusturin, C.; Liebeskind, L. S.; Rahman, H.; Sample, K.; Schweitzer, B.; Srogl, J.; Neumann, W. L. Org. Lett. 2003, 5, 4349. 